\title{
Critical agency in education: a Foucauldian perspective
}

\section{Dirk Postma}

The personal is political - Carol Hanisch, 1970

\begin{abstract}
While the neoliberal order is associated with the economy, government and globalisation, as a form of governmentality it effects a particular subjectivity. The subject is the terrain where the contest of control plays out. The subject is drawn into the seductive power of performativity which dictates its agency, desires and satisfactions and from which escape is difficult to imagine. Neoliberalism is particularly interested in an education which provides it with the much needed powers of production and consumption. This dependency of the neoliberal order on a particular kind of agential subjectivity is also its weakness because of the indeterminacy of the self. Within this openness of the human subject lies the possibility to be different and to escape any form of subjectification. Foucault's account of the critical agent portrays a form of difference that opposes and transcends neoliberal ordering. Foucault finds the principle of practices of freedom in the Greco-Roman ethics of the care for the self. It is an ethics where the subject gains control of itself through the ascetic and reflective attention in relation to available ethical codes and with the guidance of a 'master'. Such as strong sense of the self is the basis for personal and social transformation against neoliberal colonisation. The development of critical agency in education is subsequently investigated in the light of Foucault's notions of agency and freedom. The contest of the subject is of particular importance to education interested in the development of critical agency. The critical agent is not only one who could identify and analyse regimes of power, but also one who could imagine different modes of being, and who could practice freedom in the enactment of an alternative mode of being. The educational implications are explored in relation to the role of the teacher and pedagogical processes.
\end{abstract}

\section{Introduction}

Subjectivity is an important terrain of contest in the era of neoliberalism. While neoliberalism is largely used to describe the actions of governments and international corporations and processes of globalisation, it is dependent on particular kinds of individual subjectivities as both its products and its producers. 


\begin{abstract}
Neoliberalism is in the first instance a theory of political economic practices that proposes that human well-being can best be advanced by liberating individual entrepreneurial freedoms and skills within an institutional framework characterized by strong private property rights, free markets, and free trade. (Harvey, 2005, p.2) - Italics: author
\end{abstract}

The neoliberal order colonises subjectivity and transforms it into the human resources it requires. In contrast to the experiences of alienation and oppression in the industrial era, neoliberal subjects participate fully and willingly and experience satisfaction, enjoyment and rewards. Neoliberalism presents itself as a total system that is not only inevitable but also beneficial to all. It claims to ensure the best of political, educational, social, medical and scientific advances, food security and sustainable development. Total subjection to this order is therefore not only for the individual good, but also for the social and environmental good.

Education is important for neoliberalism since it provides the human capital needed for business and industry, not only in the sense of skills, but also in terms of a particular kind of subject. Peters (2001) describes such an 'enterprise education' through which the self-monitoring 'entrepreneurial self' is developed. The individual has to take 'responsibility' for the self.

The curriculum must also be redesigned to reflect the new realities and the need for the highly skilled flexible worker who possesses requisite skills in management, information handling, communication, problem solving, and decision making. (Peters, 2001, p.66)

Although the concept of the 'entrepreneurial self' suggests a self that is in control of itself and actively pursuing its own goals, it remains subjugated to the neoliberal order which narrowly predefines identity, desires, choices, goals and satisfactions. Although the neoliberal market promises freedom on the basis of the multiplication of choices, the frameworks within which it operates is narrowly delimited.

While neoliberalism contains various rewards and satisfactions, it entails two kinds of deprivation: It shapes humans in the one-dimensional form of the homo ceconomicus, and it marginalises and excludes the majority by depriving them from full participation in the world (Arendt,1998) while extracting surplus value from them and from their living spaces. It is devastating to humans and to the environment.

The neoliberal subjectification is and should be resisted. Critical agency is the reclaiming of subjectivity. Critical agency is present in many forms and 
locations of resistance (such as the Occupy-events or the Zapatistas) and in the literature of critique that draws on Marxist, Poststructuralism, Feminist, Anti-racist and Postcolonial perspectives. The limitation of acts of resistance is that they often remain within the logic and the problematic defined by the dominant order. The limitation of critique as literature is that it largely interprets and does not change the world (Marx and Engels, 1969). It is therefore important for critical agency to go beyond resistance and theorising in order to enact a different ordering. Although the nature and focus of the resistance cannot be prescribed the critical agent defines the deprivation and the appropriate form of resistance. A persistent question is consequently the nature of, and the resources available to, the agent who drives the critique and transformation. This (postmodern and poststructural) agent does not have recourse to an essential nature or to universal, transcendental or humancentered sources of critique and transformation. A conception of critical agency has therefore to be developed in the absence of universal or transcended values such as truth, rationality or the good.

This article explores perspectives that arise from a Foucauldian focus on critical agency. While Foucault is known for his investigations into forms of domination in prisons and mental institutions related to the power/knowledge nexus of the humans sciences, the underlying interest in the possibilities of freedom which only appeared in his later works, have not received equal attention. We find in the later Foucault an engagement with neoliberalism and a notion of freedom that develops from within such a dominant order. It is also a kind of agency that could resist and go beyond the seductive power of the neoliberal culture of possessiveness and consumption. It provides an opportunity to investigate how critical agents could participate in the contest of subjectivity.

This article wants to contribute to Foucauldian studies in education and to critical education studies. Although a large body of research has been done in education on the basis of Foucault's ideas (such as Ball, 2013; Besley and Peters, 2007; Olssen,1999; Popkewitz and Brennan,1998; Walshaw, 2007) the notion of critical agency has not been well developed. This Foucauldian approach to critical education studies draws on a concern it has in common with Marxist approaches of Apple, McLaren and Giroux by appealing to Marx's (1998) view of critique not as a mental activity, but as historical material action. It will be argued that a Foucauldian notion of critical agency provides the basis for the transformation of the discursive and material conditions of freedom. This article investigates the implications of 
Foucault's' notion of critical agency for a kind of education that focuses on subjectivity that challenges and transform a dominant order.

\title{
Critical agency
}

A Foucauldian notion of critical agency provides a closer account of how subjectivity could be reclaimed through its resistance against and transcendence of the neoliberal order. The summary by Kelly (2013, p.244) of Foucault's conception of critical agency is used as a framework for this analysis that will be referred to throughout:

\begin{abstract}
In general, this conception can be characterized as a subject's capacities (a) to render sensible and to critique the norms underlying any social, political, moral, aesthetic, or other practices or institutions that subjugate rather than liberate people; (b) to imagine, if not initiate, new norms that would transform the practices or institutions so they desubjugate and liberate people; and, recognizing that liberation carries its own forms of subjection, (c) to sustain this rendering, critiquing, and imagining as a permanent ethos. (Foucault, 1990d, pp.154,155; 2007, p.47)
\end{abstract}

This summary could be compared to that of Lemke (2002) for whom there are three aspects to critique: problematisation, voluntary insubordination and the audacity to expose oneself as a subject.

While (a) refers to Foucault's genealogical critique which identifies and analyses the conditions and discourses underlying forms of domination, (b) and (c) refer to a positive and constructive notion of critique. The insight into the contingency of forms of subjugation (a) contributes towards the possibility to imagine and initiate alternatives (b). But imagining and initiating do not ensure the durability of the liberation which entails a different mode of being as expressed in (c). The question that (c) wants to address is how to live after liberation, or how do we stay true to the 'event' (Badiou, 2005) of liberation? The continued existence of such a new mode of being is not dependent on a (communist) government, institutions, ethical codifications, or political parties, but on subjects that live an ethos.

It is this third aspect of critique that will be the focus of this essay. This aspect presents critique as a life-affirming practice, a way of living within, but also beyond forms of domination. It refers to an ethical kind of life that embodies critique. The positive nature of critique is expressed as follows: 
I can't help but dream about a kind of criticism that would try not to judge but to bring an oeuvre, a book, a sentence, an idea to life; it would light fires, watch the grass grow, listen to the wind, and catch the sea foam in the breeze and scatter it. It would multiply not judgments but signs of existence; it would summon them, drag them from their sleep. Perhaps it would invent them sometimes-all the better. All the better. Criticism that hands down sentences sends me to sleep; I'd like a criticism of scintillating leaps of the imagination. It would not be sovereign or dressed in red. It would bear the lightning of possible storms. (Foucault, 1997c, p.323)

When I say "critical," I don' t mean a demolition job, one of rejection or refusal, but a work of examination that consists of suspending as far as possible the system of values to which one refers when testing and assessing it. In other words: what am I doing at the moment I'm doing it? (Foucault, 1990b, p.107)

The object, rather, is to arm the subject with a truth it did not know, one that did not reside in it; what is wanted is to make this learned, memorised truth, progressively put into practice, a quasi subject that reigns supreme in us (Foucault, 1997b, p.102).

Such a positive approach to critique avoids a tendency (Leask, 2012) to separate Foucault's earlier work on subjectivity as subjugation from his later work on ethics, agency and freedom. It is, however, important to maintain the coherence in Foucault's project as expressed by him in a late interview (25 April 1984). Although Foucault shifted his focus in the later work, his central concern has always been the relation between "the subject, truth, and the constitution of experience" (Foucault, 1990a, p.48). According to Leask (2012, p.58) power is intensified in the later work of Foucault in such a way that it "came to infuse. . . the very subject that might previously have been taken to be a mere effect". Once the coherence in Foucault's work is maintained the relation between the positive notion of critique and forms of subjugation could be explored by asking how it is possible to live an ethos of freedom under the conditions of intensified subjugation? It is important to note that it is the same subjugated subject that engages in critique and develops agency. The basic point Foucault makes is that while the contest of subjectivity has become more intense in the neoliberal era the possibilities for critical agency multiply. The basis of the multiplication of possibilities is the 'care for the self'.

Holding the earlier and later work of Foucault together is also important in order to distinguish this kind of critical agent from the authentic humanistic or rational liberal subject: The Foucauldian subject is not autonomous and free from power relations. It is a non-substantive subject that does not have its own internal law (auto-nomos) by means of which authenticity could be achieved. It is always within and subjected to power relations. 
In relation to the coherence of Foucault's work, the singling out of the third aspect of critique identified by Kelly does not in any way negate the first two since the three aspects of critique are dependent on each other. The first aspect relates to Foucault's analyses of regimes of truth in relation to mental institutions, prisons and later on, sexuality. Critique is here not the mere judgement that something is wrong in relation to a set of standards, but the making explicit of the underlying norms and mechanisms of truth.

But experience has taught me that the history of various forms of rationality is sometimes more effective in unsettling our certitudes and dogmatism than is abstract criticism.

(Foucault, 1990c, p.82)

The purpose of critique is not to unmask an ideological distortion, but to show how a particular regime of truth comes into being. Insight into the contingency of the verifying and justifying norms creates the space for the other two aspects of critique: imagining how things could be different (b) and living new forms of subjectivity as an ethos (c).

While Foucault has been accused of furthering the cause of neoliberalism (Zamora, 2014), the basic approach in this article is to follow scholars such as Dilts (2011) who points to his more fundamental form of critique that is often overlooked. Leask (2012) supports this by arguing that Foucault develops an 'immanent' form of critique. This means that critique and transformation do not appeal to universal values or theories, but develops through the subversion of the dominant order and the emergence of something new that is not a mere reaction.

\section{Ethics of the self}

Critical agency should not only be defined in terms of critique and resistance (first element defined by Kelly above), but also in relation to an ethos (third element) that appeals consistently to norms that are already present in culture. This ethos refers to an ethics defined by the care for the self which Foucault develops in volumes 2 and 3 of the History of Sexuality (Foucault, 1986, $1990 \mathrm{~g}$ ). It shares with the 'ethics of care' (Nodding) the emphasis on a relational response to the particularity of the other, but differs in its primary focus on the (relational) self. 
The central themes in the work of both the earlier and the later Foucault, subjectivity, truth experience and freedom should be drawn on to understand the ethics of the care for the self. He relates ethics and freedom as follows:

Freedom is the ontological condition of ethics. But ethics is the considered form that freedom takes when it informed by reflection. (Foucault, 1997a, p.284)

The first 'freedom' refers to the liberation from relations of domination such as slavery (which could be compared with negative freedom (Berlin, 1969). Since a person can only live ethically (for Foucault) in conditions of selfmastery, this kind of freedom is the ontological condition of ethics. The second use of 'freedom' refers to an ongoing project through which a life is stylised by reflecting on the self (this could be compared with positive freedom (Taylor, 1979)). Freedom is exercised here as an ethical obligation towards the self. The ethics of the self is the continuing critique and transformation of the self and of external forms of subjugation. While freedom is the ontological condition for ethics, a positive notion of freedom is realised through an ethical life.

This ethics is primarily based on the Socratic dictum: "Take care of yourself ... Make freedom your foundation, through the mastery of yourself" (Foucault, 1997a, p.301). Freedom is exercised through reflective and ethical self-mastery. Mastery of the self is not the same as the liberal notion of autonomy because the self is always in power relations (described by Foucault as governmentality). The self could also not invent the ethical norms of life by. The question Foucault asks is therefore how freedom could be practiced within and against the dominant neoliberal morality.

Foucault finds in Greco-Roman morality his inspiration for the formulation of an ethics of the self. This ethics is very different from the Christian denunciation and negation of the self, and obedience to an e(x)ternal law. The important difference between these two kinds of ethics is the relation of the individual to prevailing ethical codes. Whereas Christian morality requires subjugation and self-denial, the subject in the Greco-Roman ethics creates an own life which draws on, but is not determined by, the existing moral codes. Ethics is not about the obedience to a moral code through which the self is redeemed, it is rather a concern with the self in relation to the moral codes present in culture (Foucault, 1997a). 
Foucault expresses this as follows:

Of course, there had also been certain norms of behavior that governed each individual's behavior. But the will to be a moral subject and the search for an ethics of existence were, in Antiquity, mainly an attempt to affirm one's liberty and to give to one' s own life a certain form in which one could recognize oneself, be recognized by others, and which even posterity might take as an example. (Foucault, 1990a, p.49)

The moral codes are not something that must simply be followed, but are rather resources to draw on in the care for the self. Foucault draws on his investigation into sexuality to illustrate this (Foucault, 1990g). The GrecoRoman morality does not simply condemn sexual relations such as those outside the marriage and including slaves and young boys. These relations are harmful in so far as they represent the submission of the self to desires which took control of the self. Such relations are not wrong because they transgress a moral code, but because they damage the self. Ethics is not about the submission to any power or code besides the particular way the self has to care for itself. The only 'transgression' is the lack of care for the self.

The ethics of the self is, furthermore, an aesthetics of existence (Foucault, 1990a), a stylising of a particular kind of life. To illustrate the aesthetic of the work on the self, Foucault points to the artist:

This transformation of one's self by one's own knowledge is, I think, something rather close to the aesthetic experience. Why should a painter work if he is not transformed by his own painting? (Foucault, 1990f, p.14)

It was a question of knowing how to govern one's own life in order to give it the most beautiful possible form (in the eyes of others, of oneself, and of the future generations for which one might serve as an example). That is what I tried to reconstitute: the formation and development of a practice of self whose aim was to constitute oneself as the worker of the beauty of one's own life. (Foucault, 1990e, p.259)

The crafting of such a life requires work on the self, disciplining of the self and self-exercise, a form of ascesis:

Care for the self is not simply an attitude, a form of living, but a practice, something for which time had to be set apart and which need to be attended to. It was seen as a 'duty and technique, a basic obligation and a set of carefully worked-out procedures. (Foucault, 1997b, p.95)

Ascetics is understood as an "exercise of self upon the self by which one attempts to develop and transform oneself, and to attain to a certain mode of being" (Foucault, 1997a, p.282). 
This ethical self is therefore not subjected to a dominating order, but it becomes a quasi-subject, a form of self-mastering. Foucault also describes this self-mastery as follows: it is to "take up residence in oneself", a selfpossession, a self-enjoyment, it is to surpass the self, and a mastery of appetites (Foucault, 1997a, p.285), an elaboration of self by self, a studious transformation, a slow arduous process of change, guided by a constant concern for truth (Foucault, 1990e).

Knowledge of and reflection on the self is an ethical search for the truth about the self. Truth should not be understood in a metaphysical or universalistic way as what corresponds with reality or what is the same for everyone. There is also no true or authentic self that has to be recovered. Truth is gained through reflection and self-knowledge in the mode of Greek dictum 'know yourself'. This truth has a negative and a positive function. Negatively it denies and resists forms of subjugation, and positively it asserts a certain sense of the self. Negatively, this truth is different from the knowledge about the self which is produced through various kinds of governmentality within regimes or games of truth. It is a realisation of who one is not, a deidentification from what one is expected to be or coerced into being. It is at the root of the self's resistance to forms of subjugation. This self is different from the entrepreneurial self enforced by the neoliberal order. Positively, truth about the self is approached through a reflection on the self in the light of ethical norms. It is the truth about the own intentions, motivations, satisfactions and desires. Freedom is the finding of and living in accordance with this enfolding truth. In line with Foucault's conception of power/truth, this truth is also an effect of the power of the self over the self. Knowledge of and truth about the self are essential to the care of the self. This knowledge is not an attempt to find the 'true self', but rather a distinctive self that is not defined by dominant forms of subjectification.

This focus on the self is not a narcissistic withdrawal within a self isolated from its role within historical material practices. The care for the self could easily be confused with the neoliberal investment in the entrepreneurial self or with a 'postmodern' playfulness and continuous invention of the self. The crucial difference is that the care for the self entails a care for others. Within the Greco-Roman ethics the good ruler, husband, father, lover or slave owner is one that, first of all, takes care of himself without which one cannot be a good ruler or be ruled in the right way (Foucault, 1997a). The abuse or domination of others in any of these relations is an indication that the person does not take care of him/herself since s/he is not in control of his/her 
passions and desires. Such lack of control is as disastrous to the self as it is to others. The care for others is therefore a constitutive element of the care for the self. The inclusion of others in the Greco-Roman ascesis is therefore in stark contrast with the Christian ascesis which entail a denouncement of the self, a withdrawal from the world and the prioritising of a vertical relationship with a deity.

The care for the self is also directly related to the transformation of the sociomaterial conditions of life. This ethics is directed against subjugated forms of governmentality embedded in social, economic and political relations. The care for the self forms the basis of the resistance against and transformation of the objective conditions of existence.

The care for the self constitutes the third element of the Foucauldian critical agency as defined by Kelly. The critical agent appears here as someone who practices his/her freedom from forms of subjugation on the basis of an ethos. The 'permanent ethos' points to a subject that continually detects and resists any form of subjugation however lucrative and 'satisfying' it might be. It is a subject set on a path of stylising him/herself in opposition to forms of subjugation within entrepreneurial governmentality. Freedom as 'agonism' refers to a continual combat, a permanent provocation (Foucault, 1982) related to the constant practice of the care for the self (Foucault, 1997b). Caring for the self takes place against the grain of neoliberal forms of subjugation. It is a continual vigilance in the face of the innovative ways in which the neoliberal ordering takes place.

While the ethics of the self draws on existing moral codes, it replaces the imposed morality of a dominant and dominating order as confirmed by Armstrong and Lemke:

Foucauldian autonomy, then, is not opposed to social regulation. Rather, it consists in the struggle to subvert the project of normalization by wresting the power of regulation from the ends of disciplinary control in order to deploy this power in the service of self-creation. (Armstrong, 2008, p.27)

The practices of freedom are forms of critique as an ethical activity. Thus, critical activity is understood as a way of self-formation - a self-formation that is neither an individual option nor a voluntaristic choice but operates in a specific normative horizon, thereby extending and transforming it. (Lemke, 2011, p.38) 


\section{Critical agency in education}

Education plays a central role in the contest of the subject. The focus on the critical agent in education is an attempt to intervene in the contested area of colonised subjectivity in order to explore ways in which such agency could be developed. This section focuses on the cultivation of a certain kind of subjectivity as an essential element of critical agency.

Neoliberalism refers to a kind of social ordering that draws on and produces the will, desires and behaviour of individuals in a holistic way. These subjectivities are dominated in the sense that their destiny is predefined within a particular order. In order for critical education to respond to this, a different relation is needed between individual subjectivity and processes of social ordering. The difference lies in the demand to become a powerful subject that relates to, opposes and goes beyond dominating forms of ordering. The focus in this section is on the pedagogical processes that could contribute to the development of this powerful agency. It attempts to answer questions such as: How could a subject within relations of power become powerful in opposition to forms of domination?; How could education as a powerful process enable the empowerment and freedom of the subject?

Some of the processes of social ordering and the production of subjectivities through education are related to the role of teacher and the kind of knowledge. A Foucauldian approach to the individual and social ordering could be contrasted with that of other educational philosophies. Humanist and constructivist approaches tend to deny the normative role of the social order as represented by the power of the teacher and objective forms of knowledge. A Freirean approach of equal dialogue does not adequately allow for the powerful intervention of the teacher and for powerful forms of knowledge, either. Rational-liberal approaches over-emphasise the presence of a dominant order within which individuals are to be initiated. None of these approaches therefore succeed in maintaining a balance between individual freedom and the social order. They either leave the subject powerless within the limited framework of the self or powerless without a sense of self in a dominant order.

It may appear that a Foucauldian response does not suffice either because he combines a non-substantive self with the demand to oppose forms of subjugation and to practise freedom. It seems that the self is left without 
resources, such as a true or rational self, in its resistance to domination. It has however been shown how critical agency is possible on the basis of Foucault's view of power, the self and freedom. It is shown that such a nonsubstantive agent can practise freedom by realising an own ethos. This section investigates how critical agency could be achieved in education by focusing on the role of the teacher and on aspects of pedagogical processes.

The aims of education

The non-substantive subject implies that the aims of education could not be specified in any substantial way in terms such as rationality or self-realisation. This also makes it harder to clearly define an oppositional self and to provide concrete content to freedom that would counter neoliberal forms of subjugation. In spite of this apparent weakness a Foucauldian approach to education insists on the development of a powerful self on the basis of an own ethos as a result of the continual work on the self. The powerful self has achieved self-mastery by defining an own morality on the basis of an interpretation and realisation of moral codes. This self is not swayed by fluctuating trends and representations demanded by the constant need for to reinvent the self. Critical agency should be developed in education by enabling children to practise their freedom by taking care of themselves (Peters, 2003).

The aim of education could be defined as the development of the self towards the "full and complete status of subject through the practice of the self" (Foucault, 2001, p.127). Although it is not expected that everyone would achieve this state of the self, it represents a fuller notion of being human. The "full and complete status of the subject" refers to a subject that has mastered him/her, know its desires, take care of the self, and live according to an ethos. The aims of education cannot be predefined in terms such as the 'critical thinker', or the 'life-long learner'. Such expectations, outcomes and standards cannot prescribe who the subject is to be. The fact that the outcomes or aims could not be clearly articulated does not leave the educational processes without direction and content. An indication of the kind of education that could develop the powerful self is discussed in relation to the role of the teacher and the pedagogical processes of teaching and learning. 


\section{Role of the teacher}

A Foucauldian conception of the role of the teacher provides some insights into the dilemma of power and freedom in education as represented by the dichotomy between the authoritarian and the egalitarian educator. This conception allocates a much stronger role to the educator when compared to humanistic and Freirean approaches. The humanist and constructivist teacher plays mainly a supportive role to assist children in the realisation of the inner and authentic self and in the discovery and construction of knowledge. Knowledge is constructed on the basis of an own frame of reference that cannot be judged in relation to a superior form of knowledge. The Freirean teacher-student, who engages in equal dialogue, refrains from exercising authority and from transmitting knowledge. The rational-liberal teacher, on the other hand, knows what children should become by initiating them into (fairly fixed and established) forms of knowledge.

In contrast to these views the Foucauldian teacher plays a powerful, but nondominating role. Although power is inherent to all human interactions and the tendency to dominate is constantly lurking, the Foucauldian teacher walks the tightrope between the exercise of power and the imposition of domination. While the exercise of power is always asymmetrical, it becomes domination when it claims to know who the child is or what $\mathrm{s} /$ he has to become. The teacher has to work with the tension between the demand for the child to define his/her own self, and the realisation that s/he cannot do this on his/her own.

While education is a life-long process through which the self works on itself, the 'other' plays an indispensable role according to Foucault. The subject cannot bring about its own transformation (Foucault, 2001). The individual needs a master in order to develop the fullness of the self. Foucault draws on Greco-Roman thinking to identify three aspects of 'mastership' (Foucault, 2001): Mastership through example, through competence and through Socratic problematisation. Since these three forms of mastership are not to be separated from each other, the relation between freedom and power should be investigated through the Socratic element within the other two forms. Foucault's emphasis on the essential role of the master points to the presence of (social) power within the heart of the educational process. It is important to investigate how this power functions in non-dominating ways since it strongly 
influences the relation of the child to the social order and the possibility to develop powerful subjectivity.

As a model the teacher's form of subjectivity is an example of the kind of subject a child could become. The master as model could be the teacher in the classroom, heroes from history or 'prestigious souls' one encounters in literature and tradition. The model is a person that has developed a 'fullness of the self' by realising an own ethos and by practising freedom and an aesthetics of existence. The Socratic questioning implicit in the modelling is the question created within the mind of the child about the particular way his/her life could be stylised. The model is not to be copied but provides an example of how aesthetics of the self could be developed and how cultural codes could be interpreted as part of a personal ethos. While it demands of the child to stylise an own life, it leaves the question open of the way it is to be done.

The mastership through competence is the passing on of knowledge and skills. This implies that there is no restriction on the responsibility of the teacher to transmit to children the wealth of knowledge and the levels of available skills. It entails the acquisition of the central concepts and processes through which knowledge is generated and legitimised. Foucault therefore does not shy away from notions of transmission and methods of lecturing. When this form of mastership is understood in relation to Socratic questioning, it entails a genealogical understanding of the contexts, processes and practices of power through which knowledge is generated and legitimised. While the acquisition of powerful knowledge is not in conflict with the understanding of its contingency, it should give occasion to the imagining of how knowledge could be different (see Kelly's point $b$ ). Essential for critical agency is the ability to understand various games and discourses of truth in order to be able to play the game differently (Foucault, 1997). An understanding of the role of the subject in the practices of knowledge production provides an alternative insight to the dominant emphasis on the consumption and the individualised possession of knowledge. In relation to the care for the self it creates a critical awareness of how the subject and the world are co-produced through knowledge practices.

The third element of mastership, Socratic mastership, takes place through dialogical questioning that works with the tension between ignorance and memory. 


\section{Pedagogy between ignorance and memory}

The Socratic questioning of the third form of mastership is a pedagogy that mediates the tension between power and freedom. It works with the nonsubstantial self and the demand to develop powerful subjectivity. The emphasis on memory indicates that knowledge is not simply gained from external sources, but through the close attention to the self.

All the forms of mastership rest on the interplay and tension between knowledge and ignorance:

\footnotetext{
The problem of mastership is how to free the young man from his ignorance. He needs to be presented with examples that he can honor in his life. He needs to acquire the techniques, know-how, principles, and knowledge that will enable him to live properly. He needs to know - and this is what takes place in the case of Socratic mastership - the fact that he does not know and, at the same time, that he knows more than he thinks he does. (Foucault, 2001, p.128)
}

Children are not freed from ignorance by simply providing them with knowledge. The master cannot know what their ignorance is or what kind of knowledge would contribute towards their freedom. The freedom from ignorance has to employ the memory of the child:

...memory being precisely what enables one to pass from ignorance to non-ignorance.

(Foucault, 2001, p.129)

Memory refers to the subject's own version of knowledge, an own interpretation of what is given, the own form of subjectivity, an own understanding of the self and the world which is not a copy of objective forms of knowledge. Memory is not simply a recall of what is memorised, but both a discovery and an expression of what you do not know you knew all along. It is not simply an expression of the true or authentic self since it requires the 'effective agency' of the master. Knowledge through memory is not the affirmation of whatever is produced by the child, but the outcome of a masterful process of questioning and prompting. It is not a process that closes the child in an inner self. Through a questioning of ignorance the child makes explicit what $\mathrm{s} /$ he already knew. Ignorance is therefore not the opposite of knowledge. The Socratic questioning does not aim to lead the child towards an objective form of knowledge, but to a knowledge that is already within the self. This does not mean that the individual already knew everything there is to know, but that an element of recognition is always present when something 
new becomes part of memory. What is to be retrieved in memory would be unique to a particular subjectivity and is both a process of discovery and construction.

Socratic questioning is a powerful tool in the hands of the master, but it also curtails his/her power. The power of the master is limited by his/her own ignorance:

\footnotetext{
He is no longer the person who, knowing what the other does not know, passes it on to him. No more is he the person who, knowing that the other does not know, knows how to demonstrate to him that in reality he knows what he does not know. (Foucault, 2001, pp.129, 130)
}

While the master transmits knowledge and skills to the child, the questioning focuses on the particular way the child memorises it by relating it to what is already known and by bringing the own subjectivity into play. The master does not know the particular version of the subjectivity of the child, the particular interpretation and realisation of moral codes, or what the subject is to become and the particular way in which the subject would stylise its life. The educator knows that subjectivity has to develop and knows how it should be done, but is ignorant about the particular form the subjectivity could take. While the master remains ignorant s/he works creatively within the tension of ignorance and memory that is essential to the development of the self. The outcome of Socratic questioning cannot be predetermined because the knowledge retrieved through memory does not correspond with ideas that may pre-exist in the mind of the master, in culture or in metaphysics.

This conception of the teacher provides a way to overcome the dichotomy between the authoritarian and the egalitarian educator. The educator needs not deny his/her own competence and authority when knowledge and competence are 'imparted' to children, but has to remain ignorant of the way it is memorised. It also points to how subjectivity could be developed in education in to mediate individual freedom and social order.

\section{Care of the self}

Another example of the important role of the master is the way powerful subjectivity is developed through the care of the self. Foucault draws on Seneca's contrast between stultitia and sapiens. Stultitia is the state where the 
care of the self is absent and manifests itself in the external determination of the self and the lack of an own will. It is state of a mind that is restless and cannot settle on anything and is not satisfied with anything:

\footnotetext{
...we can say that the stultus is first of all someone blown by the wind and open to the external world, that is to say someone who lets all the representations from the outside world into his mind.
}

[It is one who] cannot make the discriminatio, cannot separate the content of these representations from what we will call, if you like, the subjective elements, which are combined in him. (Foucault, 2001, p.131)

External determination takes place where there is no centre of the self and when one's life is constantly changed through external forces. It is brought about by an inability to discriminate between the different representations the self is confronted with. This discrimination is to be done on a sense of self developed through the care for the self.

Sapiens is when the will is changed in order to focus on the care for the self. The importance of the relation between the will and the self is expressed as follows:

The stultus is essentially someone who does not will, who does not will himself, who does not want the self, whose will is not directed towards the only object one can freely will, absolutely and always, which is oneself. (Foucault, 2001, p.133)

The individual cannot escape stultitia by him/herself because of the absence of the will to do so. The 'other' is necessary for the self to obtain sapientia which refers to self-possession and - control. The 'helping hand' of the other, represented by the figure of the philosopher in classical Greek thinking, focusses on the very mode of being of the child.

\section{Conclusion}

Critique and critical agency that focus on the analyses of and resistances to regimes of power are essential but limited because they do not necessarily escape from the frameworks they oppose. In order to challenge the reach of the processes of neoliberal ordering, critical agency has to find a kind of freedom that escapes subjugation. In order to counter subjugated forms of governmentality, it has to appeal to a centre of control within the subject 
itself. Neoliberalism does not only have to be taken on at the global terrains of politics, the economy and the environment, but also on the terrain of the subject. The subject in particular is the terrain where freedom could be practiced and control asserted.

This attention to the subject is not a withdrawal from the economic, social, political and cultural domains of struggle and transformation. It is rather an attempt to focus in more detail on the agency of transformation. This agent is not a type (rational, autonomous, desiring, oppressed, member of a class or group) but a powerful subject who takes control of itself and who practices freedom in the pursuit of an ethical, meaningful and enjoyable life.

The care for the self is an ethical command which requires close attention to the way a style of life is crafted. This self is not autonomous, but always in relations of power. Control of the self is a power over the self that replaces the power of others such as a dominant order. This self is not subjugated to external orders, but draws on cultural values in the development of an own ethos. Since freedom is a practice of self-mastery it opposes external forms of governmentality on the basis of the care for the self. The care for the self entails the shaping of the own life in order to find and experience the own form of meaning and enjoyment.

The development and fostering of critical agency in education has therefore to focus on the ethical self through which a powerful form of own subjectivity could be developed. The care for the self provides the personal, moral and epistemic strength to challenge forms of domination and to practice the kind of freedom beyond domination. The care for the self is not an ascetic withdrawal, but the basis of personal and social transformation. It is a practice of freedom that creates a style of life that generates critique of the dominant order and that anticipates the life after liberation. While the critical agent will always struggle against dominating power, this article explores critique as a constructive, life affirming process which asserts itself within and against the powerful other.

A pedagogy that aims to develop a powerful subject has to find the right balance between the mediating role of the powerful (competent) teacher and the emerging independent subjectivity of the child. It focusses on the particular way the child takes care of him/herself with reference to what is of significance in culture. The role of the teacher is to ensure that the child does not get caught up in an isolated self or get lost within a dominating other. 
These two dangers are uniquely combined in the neoliberal production of subjectivity. In order to contest this subjectivity, a strong sense of the self is needed who have developed the moral resources to craft an own form of life. It has been shown that the Foucauldian 'master' who provides powerful forms of knowledge and competence and who is limited by his/her ignorance of the mode of being of the subject is a necessary agent in the development of powerful subjectivity.

\section{References}

Arendt, H. 1998. The human condition. Chicago: University of Chicago Press.

Armstrong, A. 2008. Beyond resistance. A response to Žižek's critique to Foucault's subject of freedom. Parrhesia, 5: pp.19-31.

Badiou, A. 2005. Being and event. (O. Feltham, Trans.). London: Continuum.

Ball, S.J. 2013. Foucault, power and education. New York: Routledge.

Berlin, I. 1969. Two concepts of liberty. In Berlin, I. (Ed.), Four essays on liberty. London: Oxford University Press, pp.118-172.

Besley, A.C. and Peters, M.A. 2007. Subjectivity and truth: Foucault, education, and the culture of self. New York: Peter Lang.

Dilts, A. 2011. From "entrepreneur of the self" to "care of the self": Neoliberal governmentality and Foucault's ethics. Foucault Studies, 12: pp.130-146.

Foucault, M. 1982. The subject and power. Critical Inquiry, 8(4): pp.777-795.

Foucault, M. 1986. The care of the self. The history of sexuality, Vol III. (Hurley, R. Trans.). New York: Pantheon Books.

Foucault, M. 1990a. An aesthetics of existence. In Kritzman, L.D. (Ed.), Sheridan, A. (Trans.), Michel Foucault. Politics, philosophy, culture. Interviews and other writings 1977-1984. New York: Routledge, pp.47-56. 
Foucault, M. 1990b. On power. In Kritzman, L.D. (Ed.), Sheridan, A. (Trans.), Michel Foucault. Politics, philosophy, culture. Interviews and other writings 1977-1984. New York: Routledge, pp.96-109.

Foucault, M. 1990c. Politics and reason. In Kritzman, L.D. (Ed.), Sheridan, A. (Trans.), Michel Foucault. Politics, philosophy, culture. Interviews and other writings 1977-1984. New York: Routledge, pp.56-85.

Foucault, M. 1990d. Practicing criticism (Interview conducted by D. Eribon and published 30/31 May 1981). In Kritzman, L.D. (Ed.), Sheridan, A. (Trans.), Politics, philosophy, culture. Interviews and other writings, 1977-1984. New York: Routledge, pp.152-156.

Foucault, M. 1990e. The concern for truth. In Kritzman, L.D. (Ed.), Sheridan, A. (Trans.), Michel Foucault. Politics, philosophy, culture. Interviews and other writings 1977-1984. New York: Routledge, pp.255-270.

Foucault, M. 1990f. The minimalist self. (Discussion with S. Riggins, Autumn 1983). In Kritzman, L.D. (Ed.), Sheridan, A. (Trans.), Michel Foucault. Politics, philosophy, culture. Interviews and other writings 1977-1984. New York: Routledge, pp.3-16.

Foucault, M. 1990g. The use of pleasure. The history of sexuality, vol 2. (Hurley, R. Trans.). New York: Vintage Books.

Foucault, M. 1997a. The ethics of the concern for self as a practice of freedom. In Rabinow, P. (Ed.), The essential works of Foucault 1954-1984, Vol I: Ethics: Subjectivity and truth. New York: The New Press, pp.281-302.

Foucault, M. 1997b. The hermeneutic of the subject. In Rabinow, P. (Ed.), The essential works of Foucault 1954-1984, Vol I: Ethics: subjectivity and truth. New York: The New Press, pp.93-108.

Foucault, M. 1997c. The masked philosopher. In Rabinow, P. (Ed.), The essential works of Foucault 1954-1984, Vol I. Ethics: subjectivity and truth. New York: The New Press, pp.321-328.

Foucault, M. 2001. The hermeneutics of the subject. Lectures at the Collège de France, 1981-82. (Burchell, G. Trans., Gros, F. Ed.). New York: Palgrave MacMillan. 
Foucault, M. 2007. The politics of truth. (Lotringer, S. (Ed.), Hochroth, L. and Porter, C. Trans.). Los Angeles: Semiotext(e).

Harvey, D. 2005. A brief history of neo-liberalism. Oxford: Oxford University Press.

Kelly, M. 2013. Foucault on critical agency in painting and the aesthetics of existence. In Falzon, C., O'Leary, C. and Sawicki, J. (Eds), A companion to Foucault. Chichester: Wiley-Blackwell, pp.243-263.

Leask, I. 2012. Beyond subjection: notes on the later Foucault and education. Educational Philosophy and Theory, 44(S1): pp.57-73.

Lemke, T. 2002. Foucault, governmentality, critique. Economics, Culture \& Society, 14(3): pp.49-64.

Lemke, T. 2011. Critique and experience in Foucault. Theory, Culture \& Society, 48(4): pp.26-48.

Marx, K. and Engels, F. 1969. These on Feuerbach. In Marx/Engels Selected Works (Vol. 1, pp.13-15). Moscow: Progress Publishers. Retrieved from http://www.marxists.org/archive/marx/works/1845/theses/theses.htm

Marx, K. and Engels, F. 1998. The German ideology. Includes: theses on Feuerbach and the introduction to the critique of political economy. New York: Prometheus Books.

Olssen, M. 1999. Michel Foucault. Materialism and education. London: Bergin \& Garvey.

Peters, M. A.2001. Education, enterprise culture and the entrepreneurial self: A Foucauldian perspective. Journal of Educational Enquiry, 2(2): pp.58-71.

Peters, M.A. 2003. Truth-telling as an educational practice of the self. Foucault, parrhesia and the ethics of subjectivity. Oxford Review of Education, 29(2): pp.207-224.

Popkewitz, T.S. and Brennan, A. (Eds). 1998. Foucault's challenge: discourse, knowledge, and power in education. New York: Teachers College, Columbia University. 
Taylor, C. 1979. What's wrong with negative liberty? In Ryan, A. (Ed.), The Idea of Freedom. Oxford: Oxford University Press, pp.175-194.

Walshaw, M. 2007. Working with Foucault in education. Rotterdam: Sense Publishers.

Zamora, D. (Ed.). 2014. Critiquer Foucault: Les années 1980 et la tentation néolibérale. Paris: Éditions Aden.

Dirk Postma

Faculty of Education

University of Johannesburg

dpostma@uj.ac.za 